\title{
Seasonal Dynamics of Haemonchosis in Sheep and Goats in Tiruchirappalli District, India
}

\author{
S. Rajarajan ${ }^{1 *}$, K.M. Palanivel ${ }^{2}$, M. Geetha ${ }^{2}$ and N. Rani ${ }^{3}$ \\ ${ }^{1}$ Government of Tamil Nadu, Tamil Nadu, India \\ ${ }^{2}$ Department of Preventive Medicine, ${ }^{3}$ Department of Veterinary Parasitology, Veterinary \\ College and Research Institute, Namakkal, Tamil Nadu Veterinary and \\ Animal Sciences University, Chennai, India \\ *Corresponding author
}

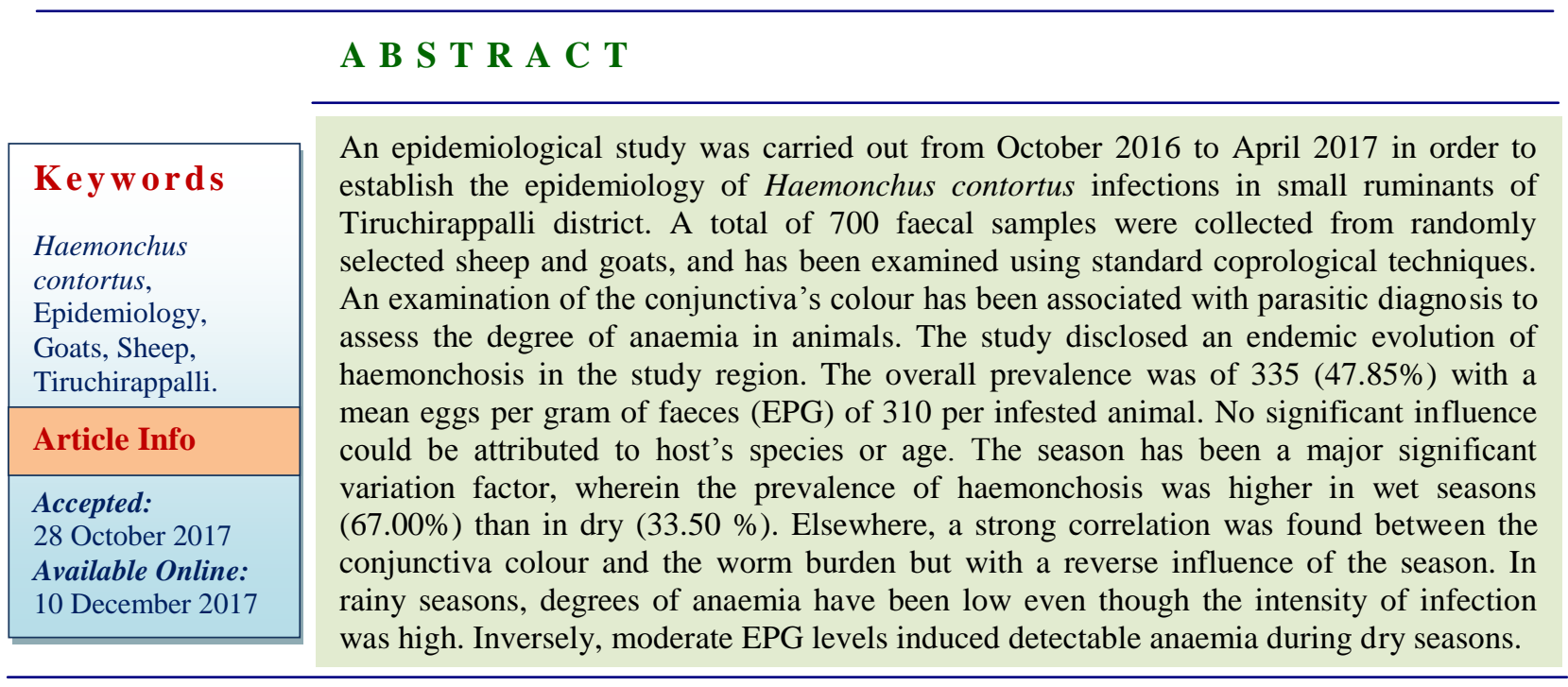

\section{Introduction}

Sheep and goats productions involve small holders living under poor conditions (traditional system with mainly family farms). The sector receives little support and is hampered by various constraints including feeding, health problem and gastrointestinal parasitism. Gastrointestinal parasitic infections in sheep and goats are major constraints in small ruminant's production system and it is an important cause of death. Environmental factors play a vital role in the parasitic infections.
For controlling gastrointestinal parasitism, information about the epizootiology of gastrointestinal parasites on a regional basis is important.

Among the gastrointestinal nematode infections in sheep and goats Haemonchus contortus has been found predominant throughout the world and also found as most pathogenic nematode. In the study region, there is very limited available information on this parasite. Thus, the parasitic risk is often underestimated or mismanaged in practice. 
Consequently, rural populations are unduly burdened by poverty while their activities may be better capitalized. This study aims to determine the prevalence and seasonal variations of haemonchosis in sheep and goats in order to propose an appropriate management plan against this impoverishing parasite.

\section{Materials and methods}

\section{Study area and duration}

The study was conducted in sheep and goats of Tiruchirappalli district, Tamilnadu (India) during October 2016 to April 2017.

\section{Study animals}

A total of 700 small ruminants including 350 sheep and 350 goats were considered during the study which includes apparently healthy and clinically affected sheep and goat of organized and unorganized farms located in the study region including government farms, constituting Two groups of ages, young $(<1$ year) and adult ( $>1$ year). Animals were identified by an individual number and some of their characteristics (species, origin, age, sex and general condition) are recorded.

\section{Study methodology}

\section{Collection of samples and data}

A total of 700 small ruminant's rectal faecal samples were collected manually in suitable containers and labeled carefully. Climatic condition of the farm area like temperature, rainfall and relative humidity were recorded and the required meteorological data like average minimum and maximum temperature, relative humidity and rainfall were taken from the government meteorological station every month.

\section{Clinical examination}

The colour of each animal's conjunctiva were examined and characterized.

Three levels of colour (red = no anaemia, pale = anaemia and white $=$ severe anaemia) have been defined and used on the basis of the FAMACHA system.

\section{Parasitological examination}

The eggs per gram of faeces (EPG) for Haemonchus contortus were estimated by the modified McMaster techniques.

Gastrointestinal nematode larvae were identified after culture of the faecal samples at room temperature for 7 days.

\section{Results and Discussion}

\section{Prevalence of anaemia}

Anaemia was detected in 204 animals out of 700 examined $(29.14 \%)$ and almost $7 \%$ (45) were severely affected.

The anaemia test seemed reliable since the colour of the conjunctiva has been strongly correlated with the worm EPG levels.

Overall and seasonal prevalence of $\boldsymbol{H}$. contortus infection in sheep and goats

Overall, (47.85\%) of the examined animals (335 out of 700) were infested by $H$. contortus. The seasonal trend of infection shows that haemonchosis is endemic in all areas without significant differences according to species or origins. The minimum and maximum recorded infection rate was (24.00\%) in April (a very dry month) and $(72.00 \%)$ in October (a very wet month) respectively (Table 3 ). 
Variation factors of $\boldsymbol{H}$. contortus infection rates

Statistically, only the season was significantly associated with the haemonchosis rates during the study. Haemonchosis has been more frequent in wet season $(72.00 \%)$ than in dry $(24.00 \%)$. There was no significant difference relating to species, sex or age (Table 1).

EPG levels of $H$. contortus and anaemic condition

The mean EPG levels of $H$. contortus were about 310. It was strongly correlated with the season. Whatever the study area, the intensity of infection was higher in wet than dry seasons. Among 204 animals classified in the anaemic groups, $204(82.35 \%)$ were really infected with Haemonchus contortus. Moreover, only $(35.88 \%)$ of non-anaemic animals were positive to Haemonchosis. Considering that the anaemia test used is reliable, Haemonchosis has been a main cause of anaemia in the examined animals (Table 1 and 2). A correlation has generally prevailed between the EPG levels and the degree of anaemia with a reverse influence of the season. In dry seasons, even moderate infestations increased significantly the level of anaemia, while in wet seasons; the intensity of infection appears not to have really influenced the degree of anaemia (Table 2).

Table.1 Prevalence of $H$. contortus infection relating to probable variation factors

\begin{tabular}{|l|l|c|c|c|}
\hline \multicolumn{1}{|c|}{ Variables } & \multicolumn{1}{|c|}{ Category } & No. examined & No. of Infected & Prevalence \\
\hline \multirow{2}{*}{ Species } & Sheep & 350 & 168 & $48.00 \%$ \\
& Goat & 350 & 167 & $47.71 \%$ \\
\hline \multirow{2}{*}{ Season } & Wet & 300 & 134 & $67.00 \%$ \\
& Dry & 400 & 201 & $33.50 \%$ \\
\hline \multirow{2}{*}{ Sex } & Male & 228 & 82 & $35.96 \%$ \\
& Female & 472 & 253 & $53.60 \%$ \\
\hline \multirow{2}{*}{ Age } & $\geq 1$ year & 467 & 196 & $41.97 \%$ \\
& $\leq 1$ year & 233 & 97 & $41.63 \%$ \\
\hline \multirow{3}{*}{ Anaemia } & Non anaemic & 496 & 178 & $35.88 \%$ \\
& Anaemic & 159 & 124 & $77.98 \%$ \\
& Very anaemic & 45 & 44 & $97.77 \%$ \\
\hline
\end{tabular}

Table.2 Prevalence (\%) of anaemia relative to $H$. contortus burden (EPG) and season

\begin{tabular}{|l|c|l|c|c|c|c|}
\hline \multicolumn{1}{c|}{$\begin{array}{c}\text { Intensity of } \\
\text { infection }\end{array}$} & \multicolumn{3}{|c|}{ Dry season } & \multicolumn{3}{c|}{ Wet season } \\
\hline EPG level & $\begin{array}{c}\text { Non } \\
\text { anaemic }\end{array}$ & $\begin{array}{l}\text { Moderate } \\
\text { anaemic }\end{array}$ & $\begin{array}{c}\text { Severely } \\
\text { anaemic }\end{array}$ & $\begin{array}{c}\text { Non } \\
\text { anaemic }\end{array}$ & $\begin{array}{l}\text { Moderate } \\
\text { anaemic }\end{array}$ & $\begin{array}{l}\text { Severely } \\
\text { anaemic }\end{array}$ \\
\hline Heavy $(>\mathbf{2 0 0 0})$ & $\mathbf{0 . 0 0}$ & $\mathbf{7 2 . 4 0}$ & $\mathbf{2 7 . 6 0}$ & $\mathbf{2 0 . 2 0}$ & $\mathbf{6 0 . 5 1}$ & 19.31 \\
\hline Moderate $(>1000)$ & $\mathbf{3 2 . 5 3}$ & $\mathbf{4 4 . 2 3}$ & $\mathbf{2 4 . 0 0}$ & $\mathbf{8 3 . 0 0}$ & $\mathbf{1 5 . 6 7}$ & $\mathbf{2 . 6 8}$ \\
\hline Low $(<\mathbf{1 0 0 0 )}$ & $\mathbf{4 9 . 6 6}$ & $\mathbf{3 5 . 8 5}$ & $\mathbf{1 7 . 5 0}$ & $\mathbf{9 2 . 0 8}$ & $\mathbf{8 . 3 3}$ & $\mathbf{0 . 0 0}$ \\
\hline None & $\mathbf{9 2 . 0 0}$ & $\mathbf{7 . 2 4}$ & $\mathbf{0 . 8 0}$ & $\mathbf{9 6 . 2 8}$ & $\mathbf{3 . 3 2}$ & $\mathbf{1 . 5 0}$ \\
\hline
\end{tabular}


Table.3 Seasonal prevalence (\%) of $H$. contortus and EPG levels

\begin{tabular}{|l|c|c|c|c|}
\hline \multicolumn{1}{|c|}{ Month } & No. Examined & No. Infected & Prevalence & Mean EPG level \\
\hline October 2016 & $\mathbf{1 0 0}$ & $\mathbf{7 2}$ & $\mathbf{7 2 . 0 0 \%}$ & $\mathbf{2 8 0 0}$ \\
\hline November 2016 & 100 & $\mathbf{6 8}$ & $\mathbf{6 8 . 0 0 \%}$ & $\mathbf{2 6 0 0}$ \\
\hline December 2016 & 100 & $\mathbf{6 1}$ & $\mathbf{6 1 . 0 0 \%}$ & $\mathbf{1 8 0 0}$ \\
\hline January 2017 & $\mathbf{1 0 0}$ & $\mathbf{4 7}$ & $\mathbf{4 7 . 0 0 \%}$ & $\mathbf{1 4 0 0}$ \\
\hline February 2017 & $\mathbf{1 0 0}$ & $\mathbf{3 3}$ & $\mathbf{3 3 . 0 0 \%}$ & $\mathbf{8 0 0}$ \\
\hline March 2017 & $\mathbf{1 0 0}$ & $\mathbf{3 0}$ & $\mathbf{3 0 . 0 0 \%}$ & $\mathbf{6 0 0}$ \\
\hline April 2017 & $\mathbf{1 0 0}$ & $\mathbf{2 4}$ & $\mathbf{2 4 . 0 0 \%}$ & $\mathbf{4 0 0}$ \\
\hline Total & $\mathbf{7 0 0}$ & $\mathbf{3 3 5}$ & $\mathbf{4 7 . 8 5}$ & $\mathbf{3 1 0}$ \\
\hline
\end{tabular}

During the study period, infestations with $H$. contortus have evolved endemic. The overall prevalence of $(47.85 \%)$ reflects the importance of these bloodsucking parasites in the study region. This is still very low compared to the prevalence reported in other countries: $82 \%$ in Togo (Bonfoh et al., 1995); 94\% in Middle Guinea (Barry et al., 2002) and 60\% in Eastern Ethiopia (Sissay, 2007). Lower prevalence also been reported elsewhere (Tariq et al., 2010; Dagnachew et al., 2011; Qamar et al., 2011).

Haemonchosis has been very prevalent in rainy seasons. This seasonal effect has already been reported in previous studies (Barry et al., 2002; Regassa et al., 2006; Sutar et al., 2010). However, contrary to some reported data (Tasawar et al., 2010; Biu et al., 2009). Age had no significant influence in the occurrence of infections. Maybe the ages clustering did not allow sufficient variability (just two groups around one year old). Similarly, no difference due to species could be established. This is not in agreement with the reports of Raza et al., (2009), but this is understandable since in the study areas, the increase in planted land is forcing sheep and goats to the same grazing way around houses or on fallow lands where the parasitic risk appears to be identical for all. And likely, the chronic nature of the infection induced some adaptive resistance. It is also possible that a combination of breed and environmental factors are responsible for this observation. Yadav et al., (1989) reported the highest EPG level during rainy season than in winter and summer. Gupta and Mathur (1969) recorded the peak parasitism with G.I parasites in sheep and goat of Tamilnadu (Madras) during the months from November to January.

The seasonal variation of EPG levels was similar to previous observations in Eastern Ethiopia (Sissay et al., 2007). EPG levels were higher in wet seasons than dry. The wet months are indeed characterized by forage availability and animals are then able to compensate the spoliation caused by worms; hence their relatively good health condition despite a significant infestation. While in dry season, anaemia is quite common despite the moderate worm burden, anaemia is due to both scarcity of forage and Haemonchosis in this period. This agrees with Vatta et al., (2002) who pointed Haemonchus spp. as one of the most important helminth in small ruminants from resource-poor areas.

This study disclosed haemonchosis is a very important parasitic disease in small ruminants in the study region. Its endemicity and intensity are likely some negative factors for productivity. However, the strong influence of the season is a favourable factor to be considered in the prophylactic fight. It would be wise to include in the control of this parasite, targeted therapies using herd management with emphasis on the seasons and the life cycle of Haemonchus spp.

\section{Acknowledgements}

The authors thank the owners of the farms for their co-operation in conducting this study and the university authorities for providing 
necessary facilities to carry out this investigation work. The authors declare that they have no conflicts of interest for publishing the data.

\section{References}

Biu, A.A.. Maimunatu, A, Salamatu, A.F, Agbadu, E.T (2009). A faecal survey of gastrointestinal parasites of ruminants on the University of Maiduguri Research Farm. Int. J. Biomed. Health Sci. 5(4): 175-179.

Bonfoh, B., Zinsstag, J, Ankers, P, Pangui, L.J, Pfister, K (1995). Epidémiologie des nématodes gastro-intestinaux chez les petits ruminants dans la région des plateaux au Togo. Rev. Elev. Méd. Vét. Pays Trop., 48(4): 321-326.

Burke, J.M, Kaplan, R.M, Miller, J.E, Terrill, T.H, Getz, W.R, Mobini, S, Valencia, E, Williams, M.J, Williamson, L.H, Vatta, A.F (2007). Accuracy of the FAMACHA system for on-farm use by sheep and goat producers in the South-eastern United States. Vet. Parasitol., 147: 89-95.

Dagnachew, S., Amamute, A, Temesgen, W (2011). Epidemiology of gastrointestinal helminthiasis of small ruminants in selected sites of North Gondar zone, Northwest Ethiopia. Ethiop. Vet. J. 15(2):57-68.

Raza, M.A., Murtaza, S, Bachaya, H.A, Dastager, G, Hussain, A (2009). Point prevalence of Haemonchosis in sheep and goats slaughtered at Multan abattoir. $J$. Anim. Plant Sci. 19(3):158-159.

Regassa, F., Sori, T, Dhuguma, R, Kiros, Y (2006). Epidemiology of Gastrointestinal Parasites of Ruminants in Western Oromia, Ethiopia. Int. J. Appl. Res. Vet. Med. 4(1):51-57.

Sissay, M.M. (2007). Helminth parasites of sheep and goats in eastern Ethiopia: epidemiology, and anthelmintic resistance and its management. Doctoral thesis, Swedish

Sutar, A.U., Kengar, S.B, Patil, S.S, Khan, M.R (2010). Prevalence of Gastrointestinal Parasites in Goats of Ahmednagar district of Maharashtra. Vet. World 3(10):456457.

Tariq, K.A., Chishti, M.Z, Ahmad, F. (2010). Gastro-intestinal nematode infections in goats relative to season, host sex and age from the Kashmir valley, India. $J$. Helminthol. 84:93-97.

Tasawar, Z., Ahmad, S, Lashari, M.H, Hayat, C.S. (2010). Prevalence of Haemonchus contortus in sheep at Research Centre for Conservation of Sahiwal Cattle (RCCSC) Jehangirabad District Khanewal, Punjab, Pakistan. Pak. J. Zool. 42(6):735-739.

Van Wyk, J.A., Bath, G.F. (2002). The FAMACHAC system for managing haemonchosis in sheep and goats by clinically identifying individual animals for treatment. Vet. Res. 33:509-529.

Vatta, A.F., Krecek, R.C, Letty, B.A, Van Der Linde, M.J, Grimbeek, R.J, De Villiers, J.F, Motswatswe, P.W, Molebiemang, G.S, Boshoff, H.M, Hansen, J.W. (2002). Incidence of Haemonchus spp. and effect on haematocrit and eye colour in goats farmed under resource-poor conditions in South Africa. Vet. Parasitol. 103:119131.

Yadav, A.K. and Tandon, V.(1989). Gastrointestinal nematode infections of goats in a sub-tropical and humid zone of India. Veterinary Parasitology, 33: 135142.

Zajac, M., Conboy, G. (2006). Veterinary Clinical Parasitology. 7th ed. Black Well Publishing Company. UK.

\section{How to cite this article:}

Rajarajan, S., K.M. Palanivel, M. Geetha and Rani, N. 2017. Seasonal Dynamics of Haemonchosis in Sheep and Goats in Tiruchirappalli District, India. Int.J.Curr.Microbiol.App.Sci. 6(12): 36453649. doi: https://doi.org/10.20546/ijcmas.2017.612.421 